\title{
Grzegorz Pyszczek
}

Akademia Pedagogiki Specjalnej im. Marii Grzegorzewskiej w Warszawie

ORCID: 0000-0003-4221-7614

DOI: https://doi.org/10.21697/ucs.2020.26.2.02

\section{INSPIRACJE MYŚLĄ FLORIANA ZNANIECKIEGO W KONCEPCJI COMMUNITAS VICTORA TURNERA}

\author{
Florian Znaniecki's thought inspiration in Victor Turner's concept of communitas
}

\begin{abstract}
Streszczenie
Przedmiotem artykułu jest wpływ myśli Floriana Znanieckiego na koncepcję communitas Victora Turnera. Pierwsza część artykułu zawiera prezentację koncepcji communitas Victora Turnera. W części drugiej przedstawiono koncepcję wspólnoty Znanieckiego, do której odwołuje się Turner. Część trzecia ukazuje związki między jedną a drugą koncepcją oraz możliwości kontynuowania refleksji zapoczątkowanej przez nie obie.
\end{abstract}

Słowa kluczowe: Victor Turner, Florian Znaniecki, communitas, wspólnota, reorganizacja kulturowa

\begin{abstract}
The article concerns Florian Znaniecki's thought inspiration in Victor Turner's concept of communitas. The first part presents the concept of community by Victor Turner. The second one deals with Znaniecki's concept of communion to which Turner referred. The last part shows the relationship between the two ideas and indicates the possibility of continuing the reflection started by both concepts
\end{abstract}

Keywords: Victor Turner, Florian Znaniecki, communitas, communion, cultural reorganization

\section{Wprowadzenie}

Wskazywanie na inspiracje swoich refleksji i prac wydaje się być dobrym i cennym obyczajem świata nauki. Umożliwia nam bowiem dostrzeżenie procesu rozwoju danej myśli, a poprzez to kontynuowanie wysiłku autora i poprzedników. Możemy się czuć wtedy, zgodnie ze znaną sentencją Bernarda z Chartres ,jak karły, które wspinają się na ramiona gigantów, by widzieć więcej od nich i dalej sięgać wzrokiem, i to nie za sprawą bystrości swojego wzroku czy wysokości ciała, lecz dzięki temu, że wspinamy się w górę i wznosimy na wysokość gigantów".

Świadectwa inspiracji intelektualnych przedstawiał odbiorcom swoich prac wybitny antropolog brytyjski Victor Turner (1920-1983)1. Co szczególnie ważne dla tego artykułu, za jednego z najistotniejszych przedstawicieli starszego pokolenia badaczy, którzy wpłynęli na kształtowanie się jego myśli, uznawał polskiego socjologa Floriana Znanieckiego (1882-1958)2.

\footnotetext{
1 Na temat biografii Turnera i podstawowych założeń jego antropologii Mathieu Deflem (2002), Rytuat, antystruktura i religia, czyli Victora Turnera procesualna analiza symboli, „Polska Sztuka Ludowa”, nr 56 (1/2).

2 Na temat biografii i socjologii Znanieckiego Z. Dulczewski (1984), Florian Znaniecki: życie i dzieto, Poznań, E. Hałas (1991), Znaczenia i wartości spoteczne: o socjologii Floriana Znanieckiego, Lublin. Na temat związków między myślą Turnera a myślą Znanieckiego E. Hałas (2007), Konwersja. Perspektywa socjologiczna, Warszawa, s. 151-155.
} 
$\mathrm{Na}$ inspirację myślą Znanieckiego wskazuje Turner w kilku zasadniczych kontekstach, np. w perspektywie koncepcji „współczynnika humanistycznego” zaprezentowanej przez polskiego socjologa. „Każde poważne studium człowieka - pisał Turner - musi podążać za nim wszędzie tam, dokąd idzie, i poważnie traktować to, co Florian Znaniecki nazwał "współczynnikiem humanistycznym«, zgodnie z którym nie tylko dla znaczenia, lecz również dla samego istnienia systemów socjokulturowych, istotny jest udział świadomych podmiotów ludzkich oraz wzajemne stosunki między ludźmi” (Turner 2005: 12-13). Każdy, kto choć trochę zna podstawowe założenia refleksji teoretycznej Turnera, akcentującej znaczenie ludzkiej podmiotowości i doniosłość zmiany kulturowej, nie może być zdziwiony tym, iż koncepcja współczynnika humanistycznego Znanieckiego musiała się wydawać brytyjskiemu antropologowi szczególnie bliska.

Już we wstępie, uprzedzając nieco treść artykułu, należy pokreślić, iż podstawowe dla obydwu badaczy koncepcje: dramatu społecznego (Turner) i reorganizacji kulturowej (Znaniecki), zawierają wiele podobnych tez i rozwiązań.

Artykuł skoncentruje się jednak przede wszystkim na powszechnie kojarzonej z nazwiskiem Turnera koncepcji communitas, za której źródła brytyjski antropolog uznaje inspirację myślą Znanieckiego. W pierwszej części artykułu zostanie zaprezentowana koncepcja communitas Victora Turnera. W drugiej koncepcja wspólnoty Znanieckiego, do której odwołuje się sam Turner. W części trzeciej zajmę się związkami między jedną a drugą koncepcją oraz możliwościami kontynuowania refleksji zapoczątkowanej przez obydwie.

\section{Koncepcja communitas Victora Turnera}

Na wstępie trzeba mocno zaznaczyć, iż wedle Turnera myśl socjologiczna Znanieckiego miała zasadniczy wpływ na samo jądro jego koncepcji teoretycznej. Turner bowiem nie był w stanie zaakceptować bardzo wpływowego w jego czasach, zarówno w socjologii, jak i w antropologii, statycznego spojrzenia na strukturę społeczną. Był przekonany co do tego, że strukturę społeczną należy ujmować przede wszystkim w aspekcie dynamicznym. To właśnie m.in. spotkanie z socjologią Znanieckiego umożliwiło mu rozwijanie jego najbardziej oryginalnych myśli.

Turner pisze o tym w sposób następujący: „Zanim jeszcze przystąpiłem do pracy terenowej, za Florianem Znanieckim, słynnym polskim socjologiem, doszedłem do przekonania, iż należy obstawać przy dynamicznym charakterze stosunków społecznych i uważać wprowadzone przez Comte’a rozróżnienie statyki społecznej od dynamiki społecznej rozwinięte później przez A.R. Radcliffa Browna i innych pozytywistów, za prowadzące w istocie na manowce. Świat społeczny cechuje stawanie się, a nie bycie (...), i z tego powodu badania struktury społecznej jako takiej są pozbawione znaczenia. Błąd zawiera się w ich podstawowym założeniu, ponieważ nie ma czegoś takiego "jak statyczne działanie" (Turner 2005: 16).

Powstaje jeszcze pytanie, na czym polegają związki między społeczną statyką a społeczną dynamiką. I w tym zakresie Turner odwołuje się do inspiracji myślą Znanieckiego oraz jego koncepcją współczynnika humanistycznego. „Raz jeszcze uznać muszę swój dług wobec F. Znanieckiego (a także wobec R. Bierstedta za jego istotny artykuł zawierający streszczenie poglądów F. Znanieckiego, Bierstedt 1976), który - podobnie jak kilku innych autorów refleksji o społeczeństwie - był skłonny utrzymywać neokantowskie rozróżnienie między dwoma rodzajami systemów - naturalnym i kulturalnym - przejawiającymi różnice nie tylko w składzie i strukturze, lecz również, co najważniejsze, w charakterze elementów, które decydują o spójności tych elementów. Systemy naturalne, jak zawsze utrzymywał Znaniecki, są dane obiektywnie i istnieją niezależnie od doświadczenia i działalności człowieka. Jeśli zaś chodzi o systemy kulturowe to wręcz przeciwnie, nie tylko ich znaczenie, lecz również samo istnienie zależy od udziału świadomego czynnego podmiotu ludzkiego od ciągłych, potencjalnie zmiennych stosunków między ludźmi. Znaniecki miał swoje własne określenie dla tej różnicy. Nazwał je »współczynnikiem humanistycznym»" (Turner 2005: 23).

Najpełniejszy wyraz refleksji teoretycznej Turnera niesie koncepcja dramatu społecznego (Turner 2005:

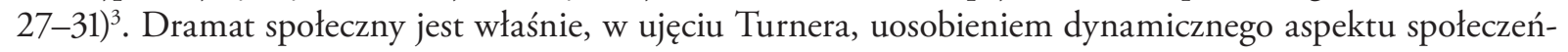
stwa, przejawem zmiany społecznej.

3 W oryginale social dramas. W języku polskim używa się także pojęcia gry społecznej. 
Dramat społeczny w ujęciu Turnera ma cztery podstawowe fazy:

- naruszenie norm społecznych,

- kryzys,

- działania przywracające równowagę,

- reintegracja.

Tak rozumiany dramat społeczny może następować wskutek oddziaływania różnych czynników, przyczyn wewnętrznych i zewnętrznych wobec struktury społecznej. Turnera intrygowały przede wszystkim przyczyny wewnętrzne, działania indywidualnych bądź grupowych podmiotów.

I tutaj powstaje zasadnicze pytanie, jakie własności posiada podmiot dokonujący lub tylko reagujący na dramat społeczny. Z reguły podmiot jest w tak znaczący sposób uwikłany w funkcjonowanie społecznej struktury, iż dokonywanie jej transformacji w znaczącym zakresie wydaje się mało prawdopodobne. Wedle Turnera dramaty społeczne jednak zachodzą. W związku z tym poszukiwał on w sferze podmiotowej warunków umożliwiających ich występowanie.

Poszukiwania Turnera zaowocowały sformułowaniem dwóch koncepcji, które w dyskursie nauk społecznych wręcz automatycznie wiążą się z nazwiskiem brytyjskiego antropologa. Są nimi koncepcja liminalności i koncepcja communitas. W szczególności ta druga, wedle samego Turnera, powstała pod wpływem Znanieckiego.

Zanim jednak powiemy o communitas, należy wspomnieć o pojęciu liminalności. To właśnie bowiem doświadczenie liminalności, innymi słowy - graniczności prowadzi do krystalizowania się communitas. Pojęcia liminalności używał Turner, inspirując się koncepcją obrzędów przejścia Arnolda van Gennepa (van Gennep 2006, Turner 2010: 115-143). W szczególności interesujące dla niego były rytuały inicjacyjne związane z wchodzeniem w dorosłość. W myśl van Gennepa w trakcie wszelakich procesów inicjacji osoby poddawane ich oddziaływaniu znajdują się niejako na granicy, w obrębie danego społeczeństwa, ale także zarazem jednocześnie poza społeczeństwem. Inicjowany to osoba pozbawiona przez krótki czas jakiegokolwiek społecznego statusu, niezintegrowana z istniejącą strukturą społeczną. Inicjowany przebywa więc na granicy i doświadcza liminalności.

W rozumieniu tego, czym jest granica, jak jest jej natura, można pójść w bardzo różnych kierunkach. Przede wszystkim można rozumieć ją społecznie, jako granicę między jednostką a grupą. Innym ujęciem jest rozumienie kulturowe, zgodnie z którym granica istnieje między dwiema kategoriami wiekowymi, które mają różne uprawnienia i różne obowiązki związane z ustanowionymi w ramach danej kultury rolami społecznymi. W końcu w pełni uprawnione jest rozumienie egzystencjalnie. Chodzi tu o doświadczanie granicy między życiem a śmiercią. Granicę tę uświadamia sobie inicjowany, przeżywając swoją egzystencją jako niepowtarzalny proces mający swój początek i koniec ${ }^{4}$. Wydaje się, iż żadna z zasygnalizowanych perspektyw nie była Turnerowi obca. Dążył on do integralnego ujmowania doświadczenia granicy jako zderzenia tego, co bliskie, z tym, co obce, we wszystkich możliwych wymiarach.

Przejdźmy jednak do krótkiej prezentacji tej koncepcji Turnera, która narodziła się m.in. jako owoc inspiracji myślą Znanieckiego. Chodzi o koncepcję communitas. Z osobą Victora Turnera na stałe wiąże się jego rozróżnienie dwóch form społecznego bytu, struktury i właśnie communitas (nazywanej także czasem antystrukturą).

Communitas można scharakteryzować najlepiej poprzez opozycję wobec struktury społecznej. „To tak jak gdyby dwa główne »modele« dla ludzkich relacji, przeciwstawne sobie i kolejno po sobie następujące. Pierwszy to społeczeństwo jako ustrukturyzowany, zróżnicowany i często hierarchiczny system pozycji

4 Tego typu liminalność najlepiej przedstawił niemiecki filozof egzystencjalny Karl Japers (1978), Sytuacje graniczne, w: R. Rudziński, Jaspers, Warszawa. Na temat granic kulturowych i społecznych m.in. brytyjska antropolog M. Douglas (2007), Czystość i zmaza, Warszawa oraz norweski socjolog F. Barth (2004), Grupy i granice etniczne: spoteczna organizacja różnic kulturowych, w: E. Nowicka, M. Kempny (red.), Badanie kultury Elementy teorii antropologicznej, Warszawa. Pojęcie granicy analizują J. Kurczewska (2005), Granica niejedno ma imię. Trzy podejścia teoretyczne, w: J. Kurczewska, H. Bojar: Granice na pograniczach: z badań spoteczności lokalnych wschodniego pogranicza Polski, Warszawa oraz G. Pyszczek (2010), Obrazy spoteczne granic Europy w świadomości mieszkańców Śląska Cieszyńskiego, w: Wyciskanie brukselki. O europeizacji spoteczności lokalnych na pograniczach, red. J. Kurczewska, H. Bojar, Warszawa. 
polityczno-prawno-ekonomicznych z wieloma typami ewaluacji, dzielący ludzi podług kryterium »mniej» lub »więcej«. Drugi, pojawiający się w okresie liminalnym, jest modelem społeczeństwa pozbawionego struktury lub ze strukturą szczątkową i ze stosunkowo niezróżnicowanym comitatus ${ }^{5}$, wspólnotą, a nawet komunią równych jednostek, które wspólnie poddają się władzy starszyzny tutualnej” (Turner 2010: 117). Przeciwieństwem hierarchii jest więc zbiorowość ludzi traktujących siebie jako równych, tworzących w pewnych okolicznościach wspólnotę.

Powstała wskutek doświadczenia liminalności communitas, aby przetrwać, musi się jednak zinstytucjonalizować: „(...) wraz ze wzrastającą specjalizacją społeczeństwa, wraz z rosnącą złożonością społecznego podziału pracy, to, co w społeczeństwie plemiennym było zasadniczo zestawem właściwości przejściowych, tych stanów "pomiędzy«, samo w sobie stało się stanem zinstytucjonalizowanym" (Turner 2010: 125). Communitas przybiera w ten sposób postać ustrukturyzowaną. Musi jednak upłynąć sporo czasu, zanim tak ustrukturyzowana communitas stanie się częścią szerszej struktury i utraci swój kontestacyjny potencjał. Przez pewien czas, aż do pełnego zintegrowania ze strukturą, pełni rolę swoistej antystruktury.

Podsumowując, Turner wyróżnia trzy podstawowe aspekty zjawiska, które nazwał communitas. Są nimi wspomniane powyżej communitas egzystencjalna, communitas normatywna oraz dodatkowo communitas ideologiczna (Turner 2010: 144). Granice między nimi nie są ostre. Częściowo ich zakresy występowania pokrywają się, przy czym najbardziej fundamentalnym przejawem communitas jest communitas egzystencjalna.

Communitas egzystencjalna jest związana po prostu z przebywaniem na granicy jakiejś zbiorowości. Wchodzą tu oczywiście w grę granice społeczne i kulturowe. Granica fizyczna, terytorialna jest o tyle ważna, o ile jest przejawem tego typu granic. Do communitas egzystencjalnej potencjalnie należą m.in. ludzie pozostający na granicy różnych klas społecznych, narodów, grup wiekowych itd. Istotne są w tym przypadku oczywiście także fundamentalne granice między życiem a śmiercią, a także wszelkie sytuacje niezadowolenia $\mathrm{z}$ danego ładu społecznego. Communitas może wytwarzać się także w sytuacjach wszelkiego zagrożenia, gdy pod wpływem zbiorowego napięcia emocjonalnego ulegają zawieszeniu sztywne podziały związane z różnymi rolami społecznymi.

Communitas egzystencjalna, prędzej czy później, instytucjonalizuje się. Powstaje communitas normatywna. W jej obrębie realnie zarysowuje się układ ról społecznych. Dopóki jednak nie zintegruje się w pełni ze strukturą społeczną, dopóty niesie z sobą potencjał pierwotnego doświadczenia liminalności.

Wedle Turnera „instytucjonalizacja liminalności nie jest wyraźniej widoczna i zdefiniowana niż w monastycznym i żebraczym stanie wielkich religii świata” (Turner 2010: 119). Formacje monastyczne powstają ze strukturyzacji pierwotnego doświadczenia liminalności. Zanim staną się częścią dominującej struktury, pełnią jednak przez krótszy lub dłuższy czas funkcję antystruktury, ożywiającej skostniałą hierarchię.

Zainteresowanie religią było jednym z czynników wpływających na kształtowanie się jego koncepcji dramatu społecznego, liminalności i communitas. Jednym z bohaterów prac Turnera był święty Franciszek z Asyżu. Wczesny ruch franciszkański, z jego dążeniem do ubóstwa, był według niego jednym z najwyrazistszych przejawów communitas (Turner 2010: rozdział 3) .

Communitas ideologiczna w końcu to wszelkiego typu wizje idealnych społeczności i zbiorowości. Wytwarzają je zarówno jednostki przeżywające doświadczenia liminalności, stanowiące communitas egzystencjalną, jak i zbiorowości stanowiące communitas normatywną. Idąc za myślą Turnera, należy powiedzieć, iż samo istnienie takich communitas ideologicznych wytwarza swoistą granicę między zbiorowością realną a idealnym projektem. Utopiści głęboko zaangażowani w tworzenie, rozważanie i przekazywanie swoich wizji sami, będąc wciąż na tej granicy, stanowią swoistą communitas egzystencjalną.

5 comitatus - łaciński termin pochodzący z Germanii Tacyta określający nieopartą na więziach rodzinnych drużynę germańskiego wodza, odznaczającą się bezwarunkową lojalnością wobec niego.

6 W 1958 r. Turner wraz z żoną Edith przystąpił do Kościół katolickiego. Wspólnie napisali znaną pracę Obraz pielgrzyma w kulturze chrześcijańskiej, Kraków 2009. Po śmierci Turnera jego żona kontynuowała prace badawcze. O relacjach między katolicyzmem i kulturą V. Turner (2013), Rytualne, plemienne, katolickie, „Christianitas”, s. 53-54. Na temat katolicyzmu Turnera w tym samym numerze Tomasz Rowiński, Wrytuatach jest życie. Turner badał różne przejawy katolicyzmu, m.in. kult świętych, kult obrazów, zakony, pielgrzymki. Często uważany jest za klasyka antropologii katolicyzmu, The Anthropology of Catholicism A Reader, Oakland 2017. 


\section{Koncepcja wspólnoty Floriana Znanieckiego}

Najmocniej jednak do kształtowania koncepcji communitas zainspirował Turnera wyartykułowany przez Znanieckiego w Metodzie socjologii obraz tego, czym jest wspólnota. Turner wprost cytuje inspirujący go fragment „Ludzie, którzy dzielą pewien zestaw połączonych systemów (a wśród tych systemów są zwykle także pewne grupy społeczne -terytorialne, genetyczne lub teliczne) - pisał Znaniecki - mogą być mniej lub bardziej świadomi tego faktu, i mniej lub bardziej chętni do wywierania na siebie wzajemnego wpływu dla dobra ich wspólnej cywilizacji oraz do wywierania wpływu na tą cywilizację dla ich wspólnego dobra. Ta świadomość, chęć o tyle, o ile istnieją, stanowią więź społeczną jednocząca tych ludzi ponad i powyżej wszelkich formalnych więzi społecznych opartych na zaistnieniu uregulowanych stosunków społecznych i zorganizowanych grup społecznych (...) Realność tej więzi przejawia się w takich znanych zjawiskach jak opinia publiczna, zbiorowa kontrola osobowości oraz grup przez środowisko społeczne, rozwój nowych ideałów kulturowych i próby ich realizacji niezależnie od zorganizowanego działania grupowego. Jeśli termin "wspólnota« ogranicza się do humanistycznej rzeczywistości, obejmującej takie zjawiska (...) jak wykształcenie nowych ideałów w kulturze i próby ich realizowania w inny sposób niż przez zorganizowane działania grupowe (...) to bez wątpienia "wspólnota" w tym znaczeniu może być badana naukowo, a socjologia jest nauką, którą bada ją jako jeden ze specyficznie społecznych faktów" (Znaniecki 2008: 130-131, cytowany w Turner 2005: 33-34).

Tak sformułowane określenie tego, czym jest wspólnota, pozwoliło Turnerowi przekroczyć widzenie społeczeństwa jako ładu społecznego opartego na hierarchii formalnych lub nieformalnych ról i statusów społecznych. Wspólnota skupiona na kształtowaniu nowych ideałów kulturowych i próbach ich realizowania to nic innego przecież, jak communitas normatywna.

Inny fragment z Gier spotecznych Turnera znacząco wskazuje na wspólne źródło inspiracji obydwu badaczy. Powyżej wskazywałem już na zainteresowanie Turnera zjawiskami religijnymi, w szczególności pielgrzymkami, którym poświęcił odrębną pracę. „W ostatniej pracy sam zwróciłem uwagę na to - pisze Turner - w jaki sposób przykład takich antystrukturalnych społeczności stanowią pielgrzymki - być może Znaniecki miał okazję obserwować communitas w Polsce, gdzie najbardziej żywiołowo objawia się ono w jasnogórskim sanktuarium Matki Boskiej Częstochowskiej, ja natomiast widziałem je w Meksyku, w bazylice Matki Boskiej z Guadelupe, a później jeszcze, w peryferyjnym sanktuarium Matki Boskiej z Knock, w hrabstwie Mayo, w Irlandii" (Turner 2005: 34, o pielgrzymkach Turner, Turner 2009).

I rzeczywiście Znaniecki, zajmując się pielgrzymkami, miał odczucia zbliżone do odczuć Turnera. W Chtopie polskim $w$ Europie i Ameryce Znaniecki wraz z Wiliamem Thomasem zwracają uwagę na to, że „zdarzają się przypadki, kiedy ludzie przyjmują mistyczną postawę w czasie nadzwyczajnych spotkań religijnych - z racji kazań misyjnych, pielgrzymek - kiedy na krótki okres zapominają o zwykłym otoczeniu i zwykłych zainteresowaniach i jednostka idąc za przykładem pobożności innych oraz pod wpływem tłumu, którego jest częścią, wznosi się ponad swój zwykły stan” (Thomas, Znaniecki 1976, t. 1: 227). Podobieństwo do przeżyć związanych z doświadczaniem liminalności wydaje się tu być bardzo bliskie.

Tak jak osią poszukiwań antropologicznych Turnera była jego koncepcja dramatu społecznego, tak pewne centrum badań socjologicznych Znanieckiego stanowiła jego wizja reorganizacji kulturowej (Znaniecki 1971, Pyszczek 2016, Thomas i Znaniecki 1976, t. IV, używają zbliżonego pojęcia reorganizacji społecznej). To właśnie w tym kontekście należy odczytywać jego koncepcję wspólnoty, która ma być czynnikiem sprzyjającym dokonywaniu zmian, a która tak zainspirowała Turnera. W wielu aspektach wydaje się ona być bardzo podobna do koncepcji dramatu społecznego brytyjskiego antropologa.

Reorganizacja kulturowa jest w koncepcji Znanieckiego odpowiedzią na dezorganizację kulturową. Ta ostatnia polega na znaczącym nierespektowaniu norm uznawanych w danym społeczeństwie za słuszne. Dezorganizacja kulturowa inicjuje dwa konkurencyjne ze sobą procesy: reorganizację zachowawczą dążącą do obrony starego ładu oraz reorganizację twórczą dążącą do nowych form życia społecznego, które będą neutralizowały przyczyny zachowań związanych z łamaniem norm. O ile reorganizacja zachowawcza dąży do sprawniejszych represji związanych z zachowaniami dewiacyjnymi oraz do wzmocnienia internalizacji norm, o tyle reorganizacja twórcza związana jest z odkrywaniem nowych norm i budowaniem nowych instytucji. 
Jak może wyglądać ten ostatni proces, proces reorganizacji twórczej? Pewną ilustracją tego są zawarte przez Znanieckiego i Thomasa w Chtopie polskim w Europie i Ameryce opisy polskiego ruchu chłopskiego z początku XX wieku reorganizującego życie wiejskie. Opisując ten proces, należy wedle nich wyróżnić pięć podstawowych czynników. Są nimi „1) przewodnictwo, 2) kształcenie chłopów, 3) szersza społeczność i prasa, 4) instytucje spółdzielcze, 5) rola klasy chłopskiej w narodzie” (Thomas, Znaniecki 1976, t. IV: 113). Czynnikiem podstawowym, pierwszorzędnym jest przywództwo, określane tu jako przewodnictwo.

Nie każdy jednak rodzaj przewodnictwa może być podstawą procesu reorganizacji społecznej. Autorzy wyróżniają trzy typy przewodnictwa - oparte na obawie i nadziei, oparte na prestiżu, oparte na dokonaniach (Thomas, Znaniecki 1976, t. IV: 127). Typ pierwszy, ich zdaniem, nie nadaje się do przewodzenia w dziele reorganizacji społecznej. Polega on na dystrybucji kar i nagród. Musi być związany z istniejącymi już instytucjami, które dysponują określonymi zasobami. To jednak właśnie te instytucje są cząstką zdezorganizowanego systemu społecznego, którego dezorganizacji zapobiec nie mogły. Istotą ich trwania jest dążenie do zachowania i wzmacniania status quo. Nie są więc z reguły sojusznikami w dokonywaniu pożądanych zmian, co najwyżej starają się zachować dawne formy systemu społecznego.

W dziele reorganizacji społecznej istotne są natomiast pozostałe dwa typy przewodnictwa oparte na prestiżu (wynika on z pozycji społecznej) oraz szczególnie ceniony przez Znanieckiego i Thomasa - oparty na własnych dokonaniach. W szczególności ten ostatni typ przewodnictwa ma szansę tworzyć nowe formy współdziałania oraz pobudzać, poprzez przykład, aktywność tych, którzy temu przewodnictwu podlegają.

Ten typ nieformalnego przywództwa intrygował Znanieckiego w całej jego biografii intelektualnej. W okresie po opublikowaniu Chtopa polskiego w Europie i Ameryce zamiast pojęcia „przewodnictwa” używał innego, zbliżonego terminu „przodownictwo”.

O przodowniku pisze w sposób następujący „...) tylko bowiem przodownik wyżej od grupy posunięty w rozwoju, lecz nie na tyle wyżej, by grupa współdziałać z nim nie mogła, jest w stanie natchnąć grupę wspólnym ideałem i skłonić do czynów dla tego ideału. Każda grupa młodzieńcza musi więc mieć przodownika, który, sam będąc członkiem bardziej rozwiniętych grup i sam podlegając wpływom wyższych od siebie przodowników, udzielałby zaczerpniętego od nich rozmachu czynnego i idealizmu mniej rozwiniętym współpracownikom. Muszą to być jednak tylko przodownicy, sami uczestniczący w działaniu grup, którym przodują, jako „pierwsi wśród równych”. Nie mogą być ani rządzącym z góry „władcami”, ani kierującymi z zewnątrz „pedagogami”. Władcy mogą bowiem podwładnych wprawić w działanie, ale nie mogą ich nauczyć tego, by czyny swe samodzielnie kierowali ku ideałowi. Pedagodzy mogą wychowankom zaszczepić uznanie i zrozumienie dla ideałów, ale nie mogą sprawić, by ideał samodzielnie wywoływał czyny, potrzebne do jego urzeczywistnienia” (Znaniecki 2001, t. 2: 379). W powyższych słowach „przodownictwo” jest ukazane w kontekście procesów wychowania, którymi Znaniecki żywo się interesował. Sama jednak idea lidera, aktywizującego swoje otoczenie poprzez własny przykład i swoją osobistą wizję przyszłego stanu rzeczy może, wedle Znanieckiego, pojawić się i pojawia się we wszystkich sferach życia społecznego.

To właśnie przodownicy są gwarancją dokonania autentycznej zmiany kulturowej i społecznej. Krąg skupiony wokół przodownika to właśnie wspólnota ${ }^{7}$ Tak rozumiana wspólnota wybiega poza zarysowany przez Ferdinanda Tönniesa dualizm dwóch podstawowych form społecznych, Gemeinschaft oraz Gesselschaft (Tönnies 1988). Przystąpienie do niej wymaga wyboru, podobnie jak przystąpienie do Gesselschaft, obejmuje ona jednak nie tylko pewną część życia jednostki, lecz jego całość, podobnie jak Gemeinschaft. Rzeczywiście tego typu wspólnota bardzo przypomina Turnerowską communitas i można ją śmiało usytuować między

7 Temat przodownictwa jest ściśle związany z innym charakterystycznym motywem socjologii Znanieckiego, czyli dewiacją pozytywną, nonkonformizmem prospołecznym. Zasadniczo można założyć, iż każdy przodownik jest dewiantem społecznym, choć nie musi być odwrotnie. Tematowi dewiacji pozytywnej m.in. poświęcił Znaniecki swoją pracę Ludzie teraźniejsi a cywilizacja przysztości, Lwów - Warszawa 1935 (ostatnie wydanie Warszawa 1935). Refleksje Znanieckiego kontynuował po II wojnie światowej Jerzy Kwaśniewski (1976) Pozytywna dewiacja spoteczna, „Studia Socjologiczne”, nr 3 oraz w studium Pozytywna i negatywna dewiacja spoteczna - funkcja wartościujących ocen i reakcji emocjonalnych, w: tenże (1983), Spoteczeństwo wobec dewiacji, Warszawa. W następnym pokoleniu problem podjął Grzegorz Pyszczek (2013), Nadnormalność jako zjawisko spoteczne. Wokót koncepcji Floriana Znanieckiego. Warszawa. 
communitas egzystencjalną a communitas normatywną. Konkretne przykłady takich wspólnot podaje Znaniecki w pierwszym tomie swojej Socjologii wychowania (Znaniecki 1973, t. 1: 390-393).

Więcej uwagi tego typu wspólnocie, która tak zaintrygowała Turnera, poświęcił Znaniecki w opublikowanej mniej więcej w tym samym czasie co Metoda socjologii anglojęzycznej pracy Social Action.

Social Action jest jednym z najpełniejszych wykładów poglądów socjologicznych Znanieckiego. Jego koncepcję wspólnoty, którą nazywa wspólnotą synergetyczną, napotykamy w rozdziale poświęconym altruizmowi. Tak określony kontekst w dużej mierze definiuje to, czym jest ze swej natury tego typu wspólnota.

Jej podstawowym atrybutem jest właśnie skierowanie na zewnątrz, poza sferę potrzeb grupowych i potrzeb indywidualnych poszczególnych członków. Celem jest realizacja różnego typu ideałów kulturowych.

Uformowanie się wspólnoty synergetycznej jest efektem dłuższego procesu społecznego. Jego pierwszym etapem jest powstanie czegoś, co Znaniecki nazywa wspólnotą synestetyczną, wspólnotą doświadczenia. Wspólnota doświadczenia to wspólnota postrzegania i interpretowania świata. Członkowie wspólnoty doświadczenia widzą w ten sam sposób określony zestaw spraw i problemów. Ujmują go w zasadniczo podobny sposób.

Jak pisze sam Znaniecki, „komunikacja społeczna, zamiast być tylko częścią niektórych innych działań, może być również pełnym, samodzielnym działaniem społecznym, służąc wyłącznie celowi, jakim jest ustanowieniem pewnej jedności między różnymi podmiotami społecznymi. W tej sytuacji możemy mówić o wspólnocie synestetycznej" (Znaniecki 1967: 521).

Wspólnota doświadczenia, postrzegania może przekształcić się we wspólnotę przeżywania emocji, wspólnotę sympatetyczną. Wspólnota sympatetyczna to wspólnota postaw. W grę wchodzi nie tylko podobne doświadczanie świata, ale zajmowanie wobec niego i różnych jego aspektów podobnych postaw. Jest to oczywiście połączone z przeżywaniem podobnych emocji i uczuć wobec określonej klasy przedmiotów. Te same zdarzenia, osoby, przedmioty budzą wspólną fascynację i sympatię lub wspólną odrazę i niechęć.

Jak pisał Znaniecki, „W sytuacji gdy jestem osobiście entuzjastą jakiegoś dzieła sztuki lub jestem oburzony jakąś instytucją, pytanie, czy mój przyjaciel podziela lub nie podziela mojego entuzjazmu lub oburzenia staje się kwestią "psychologicznej harmonii« między nami. I odwrotnie, jeśli zauważę, że mój przyjaciel jest entuzjastą czegoś lub jest czymś oburzony, to zwykle, ze względu na niego, podzielam jego entuzjazm lub oburzenie, mimo tego, że sam nie poczułem tego pierwotnie. Mogę nawet zmienić lub udawać, że zmieniam mój sposób wartościowania, jeśli w określonych sprawach nie zgadza się z jego sposobem wartościowania, ponieważ jego uczucia mogą być dla mnie cenniejsze niż jakieś określone dzieło sztuki czy instytucja. W obu przypadkach rezultatem, do którego dążę, jest sympatia społeczna, wspólnota uczuć z moim przyjacielem, którą można nazwać współczującą wspólnotą" (Znaniecki 1967: 537).

W końcu pojawia się wspólnota synergetyczna, wspólnota działań. Jej podstawą musi być wytworzenie wspólnych motywów tego działania. Z taką sytuacją mamy do czynienia, wedle Znanieckiego, wtedy, gdy „jakiś podmiot próbuje przekazać własne motywy innym podmiotom, które już współpracowały z nim w dążeniu do wspólnego celu lub zostały skierowane do tej współpracy. Czasami zewnętrzne oddziaływanie tego podmiotu spotyka się, jak gdyby w pół drogi, z spontanicznymi wewnętrznymi reakcjami z drugiej strony. Podziw uczniów może być nie tylko reakcją na myśli myśliciela, wysiłki naukowca lub artysty, którzy chcą przekazać im swój własny twórczy entuzjazm, lecz może wynikać z ich własnej inicjatywy, ponieważ doceniają ten entuzjazm jako wartościowy psychologiczny motyw. Innym razem nie mamy do czynienia z wyznawcami, lecz z przywódcami, którzy wewnętrznie podzielają motywy tych, którymi chcą przewodzić i znaleźć wspólne cele, aby je zaspokoić. Tak więc np. nie kierujący się osobistym interesem przywódca związkowy współodczuwający z cierpieniem pracowników, którzy z trudem dążą do zachowania lub osiągnięcia minimum egzystencji dla siebie i swoich rodzin, prowadzi ich do zbiorowego działania tworząc związek zawodowy, aby osiągnąć cel, jakim jest poprawa warunków życia tych pracowników” (Znaniecki 1967: 549-550). Takie podzielanie motywów prowadzi do wytworzenia się wspólnoty synergetycznej, wspierającej się na podstawach wcześniejszych wspólnot, synestetycznej i sympatetycznej.

Wspólnota synergetyczna jest wspólnotą dążenia, dążenia altruistycznego przekształcającego świat. Jeżeli daje wsparcie lub pomaga realizować interesy, to tylko w sposób wtórny, wobec realizacji swojego podstawowego cel. 


\section{Powinowactwa myśli Znanieckiego i Turnera}

Odwołania Turnera do myśli Znanieckiego ujawniają głębokie powinowactwa intelektualne obydwu socjologów. Obu ich fascynowała spontaniczna dążność społeczeństw do zmian, do oddolnej samoorganizacji. Turner i Znaniecki drążą ten sam problem, każdy z nich podchodzi jednak do niego od innej strony. Turnerowska teoria dramatu społecznego oraz koncepcja reorganizacji kulturowej Znanieckiego zawierają wiele podobnych rozwiązań. Stanowią ponadto podstawę dorobku intelektualnego obydwu myślicieli.

Turner szuka w obrębie struktury społecznej tych obszarów, które mogłyby stanowić swoiste zarzewie pojawiania się dążeń do bardziej zasadniczej zmiany społecznej. Poprzez ujawnianie obecności swoistej antystruktury wiążącej się z rozmaitymi fragmentach struktury społecznej mamy wgląd w areny potencjalnych narodzin nowych form życia społecznego.

Tak rozumiana antystruktura jest ściśle powiązana z doświadczeniem granic, doświadczeniem liminalności, mówiąc językiem Turnera. W grę wchodzą wszelkiego typu granice, zarówno fizyczne, jak i społeczne i kulturowe. Doświadczenie liminalności wytrąca jednostki z pełnienia przez nie określonych ról społecznych. Jest doświadczeniem negatywnym, gdyż destabilizuje zarówno osobowość jednostki, jak i równowagę stosunków społecznych. Jest doświadczeniem pozytywnym, gdyż ukazuje potencjał rozwoju, zarówno jednostki, jak i grupy. Granica ma charakter ambiwalentny, jednocześnie odpycha i przyciąga.

Dobrą ilustracją koncepcji Turnera dotyczącą znaczenia doświadczenia granic w życiu społecznym są bardzo popularne w swoim czasie poglądy amerykańskiego historyka Fredericka Jacksona Turnera (1861-1932) związane ze znaczeniem pogranicza dla kształtowana się społeczeństwa i kultury Stanów Zjednoczonych. Według niego trwające wiele dekad doświadczenie obecności rozległego pogranicza i towarzyszące mu doświadczenia przekraczania pogranicza i zagospodarowywania nowych ziem ukształtowało specyficzną dla USA mentalność pioniera nie wahającego się podążać w stronę nieznanego.

Według Fredericka Jacksona Turnera „(...) na pograniczu, nieustannie zrywane są więzy zwyczajów i zwycięża wolność od ograniczeń. Nie ma tam tabula rasa. Jest za to uparte amerykańskie środowisko ze swoim władczym wezwaniem, aby zaakceptować jego warunki. Znajdziemy tam również odziedziczone sposoby działania, ale wciąż, mimo środowiska i zwyczaju, każde pogranicze otwiera nowe pole możliwości, bramę ucieczki od niewoli przeszłości, dając świeżość i pewność, której towarzyszą pogarda dla starego społeczeństwa, irytacja z powodu jego barier i idei oraz obojętność na jego lekcje. Tym, czym było Morze Śródziemne dla Greków, zerwaniem z dawnymi zwyczajami, ofertą nowych doświadczeń, powołaniem nowych instytucji i początkiem nowych działań, tym, a nawet czymś więcej, stało się wciąż powracające pogranicze (...) dla USA" (Turner 2014: 25).

Bez wątpienia mamy tutaj do czynienia z doświadczeniem liminalności oraz symptomami kształtowania się communitas będącej skutkiem tego zbiorowego doświadczenia.

Jednym z głównych motywów poszukiwań badawczych Turnera było jednak poszukiwanie podstaw formowania się więzi i relacji społecznych na podstawie tak rozumianego doświadczenia liminalności. To właśnie tutaj znalazł oparcie w koncepcji wspólnoty Znanieckiego, która była dla niego inspiracją do poszukiwań różnego typu form, tego, co sam nazwał communitas.

Czy jednak doświadczenie liminalności nie jest w pewnym zakresie zapośredniczone społecznie i kulturowo? Czy czasami nie jest tak, że aby go w pełni doświadczać, nie należy pozostawać już w pewnym społecznym i kulturowym kontekście?

Po pierwsze, odwołując się do rudymentarnej wiedzy psychologicznej, należy sobie uświadomić to, iż doświadczenia tego typu mogą być po prostu tłumione. Wynika to z tego, iż doświadczenie liminalności jest ściśle powiązane z ambiwalencją zachowań i postaw X. (Merton 1976). Jest doświadczeniem jednoczesnego przyciągania i odpychania, które może być traumatyczne. Na doświadczenia tego typu trzeba się po prostu otworzyć.

Po drugie, nawet to uświadomione i przeżywane doświadczenie liminalności może zmieniać swój kształt. Granica oddziela sferę tego, co znane i oswojone, od tego, co obce, nieprzewidywalne. Kształt granic wyznaczają ludzkie doświadczenia, zarówno te jednostkowe, jak i te zbiorowe. Wraz z upływem czasu granice mogą się oddalać bądź zbliżać do doznającego ich podmiotu. 
W obydwu wymienionych przypadkach należy sobie zadać pytanie, kto i w jakiej sytuacji może wpływać na kształt doświadczenia liminalności oraz na postawy otwarcia bądź zamknięcia na to doświadczenie ${ }^{8}$.

To, co było punktem dojścia dla Turnera, stanowiło punkt wyjścia koncepcji reorganizacji społecznej i kulturowej Znanieckiego. Turner od zbiorowego doświadczenia liminalności przechodził do communitas egzystencjalnego, która następnie przechodziła w communitas normatywną posiadającą pewną rudymentarną strukturę.

Dla Znanieckiego punktem wyjścia była właśnie ta struktura. Chodziło mu o nieformalny krąg wspólnotowy skupiony wokół lidera, przodownika. To on miał dokonywać reorganizacji kulturowej bądź społecznej.

Znaniecki opierał się w dużej mierze na osobistych doświadczeniach. „Najbardziej interesującym momentem w (...) ruchu samowychowania jest to, że jego rezultaty w uderzający sposób sprawdziły się w ciągu ostatnich dziesięciu, piętnastu lat - pisał Znaniecki - Ktokolwiek zna sytuację polityczną Polski przed wojną [I wojną światową - przypis autora] (...) ten musi zdawać sobie sprawę, że zadanie, w obliczu którego stanął naród, odbudowania w kilka lat pełnego systemu państwowego było niezwykle trudne (...) I teraz fakt, że problem ten rozwiązano mniej lub bardziej zadawalająco, zawdzięczamy przede wszystkim treningowi stawiania czoła nowym problemom, który przeszła większa część polskich intelektualistów w młodości, biorąc udział w ruchu samowychowania. W rzeczy samej, ogromna większość tych, którzy od wojny odgrywali z powodzeniem przywódczą rolę we wszystkich dziedzinach życia publicznego całej Polski, była w młodości aktywnymi członkami studenckich stowarzyszeń i więcej zawdzięczała samowychowaniu niż szkołom” (Znaniecki, Wychowanie i samowychowanie w nowoczesnych spoteczeństwach, za L. Turos, 1995).

Trzeba wspomnieć, iż uczestnikiem ruchu samowychowania był sam Znaniecki, zarówno w roli wychowanka, jak i wychowawcy. Tak wspominał te lata: „Mimo bowiem złych warunków materialnych znalazłem tu wyjątkowo dobrą atmosferę społeczno-moralną. Intelektualiści cieszyli się niezwykłym prestiżem i zainteresowaniem ze strony wszystkich warstw społecznych. (...) Tak na przykład, gdy opublikowałem książkę filozoficzną - dla przeciętnego czytelnika bardzo trudną - szczegółowe opracowania o niej zamieściły nie tylko czasopisma bibliograficzne i filozoficzne, ale także popularne magazyny i prasa codzienna. Pamiętam obszerną recenzję, ciągnącą się przez dwa kolejne numery pewnego miesięcznika oraz inną, zajmującą całą stronę drukowaną w jednym z czołowych dzienników. Pisały je osoby, do których nikt się o to nie zwracał i których najczęściej nie znałem. Żyjąc w takim środowisku, wśród pracowników nauki wykazujących najwyższe aspiracje naukowe, inspirowanych nie kończącymi się dyskusjami, zawsze skłonnych służyć krytyczną konsultacją, opinia bądź oceną, zagłębiłem się całkowicie i z przyjemnością w dociekaniach teoretycznych. W ciągu trzech i pół lat mego pobytu w Warszawie wykonałem więcej pracy twórczej niż niejeden naukowiec akademicki, prowadzący zajęcia dydaktyczne” (Znaniecki 1978, na temat kontekstu biograficznego aktywności Znanieckiego: Pyszczek 2013: 44-56). Ruch samowychowania, jak nazwał go Znaniecki, był szeregiem powiązanych nieformalnych kręgów skupionych wokół nieformalnych liderów.

Dla Znanieckiego pewną podstawą myślenia o dokonywaniu zmian społecznych jest możliwość istnienia jednostek, których społecznego funkcjonowania nie dałoby się sprowadzić wyłącznie do pełnienia ról społecznych. Jednostki inicjujące zmiany społeczne muszą wyrastać ponad społeczny konformizm, kierować się w stronę uniwersalnych zasad i wzorców. Być może najpełniej wyraził to Znaniecki w swej koncepcji nadnormalności. Nadnormalny, czy też używając terminologii polskiego socjologa, zboczeniec pozytywny, gromadzi

8 Problemy liminalności i granicy są ściśle powiązane z tematyką swojskości i obcości. Oprócz klasyków socjologii F. Znaniecki (1990), Studium nad antagonizmem do obcych, w: tenże, Wspótczesne narody, Warszawa, A. Schutz (2008), Obcy: esej z zakresu psychologii spotecznej, w: tenże: O wielości światów. Szkice z socjologii fenomenologicznej. Kraków, G. Simmel (2005) Obcy. w: tenże: Socjologia, Warszawa, z nowszej literatury warto wymienić m.in. E. Nowicka (1990), Swojskość i obcość jako kategorie socjologicznej analizy, w: Swoi i obcy, red. tejże, Warszawa, B. Waldenfels (2002), Topografia obcego. Studia z fenomenologii obcego, Warszawa. Ciekawe ujęcie antropologiczne przedstawił Z. Benedyktowicz (2000), Portrety obcego. Od stereotypu do symbolu. Kraków. Rzadko poruszany problem ksenofilii podjął G. Pyszczek (2015), Ksenofilia jako fenomen kulturowy, „Górnośląskie Studia Socjologiczne. Seria Nowa”. Interesująca teorię zwrotu inkorporacyjnego zaproponował T.M. Korczyński (2019), Kiedy dom zaczyna ptonąć. Swój, obcy, wróg w Trzeciej Rzeszy - perspektywa konstruktywistycznej socjologii wiedzy, Warszawa. Z problematyką granic ściśle związana jest kwestia transgresji granic, czyli ich przekraczania. Podejmują ją m.in. z pozycji filozoficznych G. Bataille (1998), Doświadczenie wewnętrzne. Warszawa, a z pozycji psychologicznych J. Kozielecki (1997), Transgresja i kultura, Warszawa. 
wokół siebie, lub raczej wokół głoszonej przez siebie idei, nieformalny krąg zwolenników. To oni stanowią podstawę tego, co sam Znaniecki nazywał wspólnotą, której przodownikiem jest właśnie nadnormalny.

Znów sięgnijmy do autobiograficznych świadectw Znanieckiego, aby pokazać, jak ważny dla niego był ten ideał. „To, czego chciałem, miało być szybkim, bezpośrednim, silnym emocjonalnie oddziaływaniem na masy, docierającym wszędzie w łatwy sposób. Moją wyobraźnie podniecały przykłady wielkich twórców religii i reformatorów W stanie egzaltacji którym się znalazłem w wyniku anormalnego życia społecznego, mego zabsorbowania poezją, a prawdopodobnie stłumionych i silnie wyidealizowanych potrzeb seksualnych, idea stania się twórcą religii, proklamującym »religię etycznąu typu buddyzm, lecz radykalnie różną od buddyzmu w jej optymistycznej afirmacji życia, była zbyt sugestywna, by nie podjąć próby jej realizacji. Dzieła Nietzschego, które czytałem wtedy po raz pierwszy, pomogły w krystalizacji planu" (Dulczewski 1984: 36).

Koncepcja tego typu wspólnoty, opisywanej przez Znanieckiego, występuje w socjologii dość rzadko, nie jest jednak zupełnie nieobecna9. Elżbieta Hałas (2007: 149) komentując myśl Turnera i Znanieckiego, odwołuje się np. do koncepcji Bundu Hermana Schmalenbacha $(1977)^{10}$. Wedle Schmalenbacha Bund ma być trzecią formą życia społecznego, obok Gemeinschaft i Gesselschaft, podlegającą wyborowi, nieopierającą się jednak na wymianie dóbr. W podobnym kierunku szedł także amerykański socjolog Robert Nisbet w swej koncepcji wspólnot ekologicznych. Nisbet pisał: „W historii Zachodu od upadku Cesarstwa Rzymskiego w pewnych okresach spotykamy grupy odwracające się od ustanowionego porządku społecznego i wycofujące się do bardziej lub mniej odległych miejsc, aby szukać odnowy tego, w co wierzą, że jest ludzką naturalną tendencją ku prawdziwej wspólnocie i moralności" (R. Nisbet 1973, The Social Philosophers. Community and Conflict in Western Thought, New York: 319, za Skudrzyk 2001).

W wiele lat po Znanieckim tego typu problematykę podjął zainspirowany ruchem „Solidarności” Tadeusz Szawiel. W jego studium dotyczącym oddziaływania grupy etosowej na społeczeństwo czytamy: „na tle społeczeństwa, w pewnym metaforycznym sensie "magmy« pojawiają się ogniska skupienia, wokół których narasta coś pod ważkimi względami jednorodnego. W przeciwieństwie do hierarchii warstw grup społeczno-zawodowych czy klas te ogniska skupienia-grupy lokują się nie tyle "nad" czy "pod" względem siebie, ale lokują się "obok" siebie. (...) wymiana zachodzi przede wszystkim między grupą a "społeczeństwem-magmąu, natomiast prawie w ogóle nie zachodzi między grupami” (Szawiel 1982: 169).

Znanieckiemu nie była obca problematyka granicy. Podejmował kwestię kontaktu z obcymi i obcością, poświęcając jej odrębną pracę (Znaniecki 1990). Kształtował swoją własną koncepcję obcości, według której „przedmiot ludzki doświadczany jest przez podmiot ludzki jako obcy zawsze wtedy i tylko wtedy, gdy zachodzi między nimi styczność społeczna na podłożu rozdzielnych układów wartości” (Znaniecki 1990: 300). Generalnie trudno jednak znaleźć powiązanie tej problematyki z zagadnieniami reorganizacji kulturowej. A jak się wydaje, obawa przez innymi, jak i pragnienie inności, obcości mogą być zasadniczymi siłami prowadzącymi do zmiany kulturowej. Tutaj bezwzględnie należy przyznać rację Victorowi Turnerowi. „Coś jest w tej mierze, jakie ma granice" - jak powiedział filozof rumuński Gabriel Liiceanu (2018)

Przodownika wspólnoty, rozwijając koncepcję Znanieckiego, można by jednak ujmować jako postać otwierającą na doświadczenie liminalności, na bardziej adekwatne rozumienie tych doświadczeń. W takiej perspektywie koncepcje Turnera i Znanieckiego można by widzieć jako komplementarne wobec siebie.

\footnotetext{
9 Trzeba także wspomnieć o szeroko dyskutowanej w psychologii społecznej koncepcji wpływu mniejszości, rozpropagowanej pod wpływem jednego z klasyków socjologii Gabriela Tarde, Serge Moscovici, która ma punkty styczne z tą koncepcją socjologiczną. 10 Schmalenbach opierał się także na własnych doświadczeniach biograficznych. Punktem odniesienia dla niego był George-Kreis, ideowy krąg artystyczno-intelektualny skupiony wokół znanego niemieckiego poety Stefana George.

11 Każdy, kogo interesują zagadnienia liminalności i communitas, powinien sięgnąć do książki tego autora pt. Dziennik z Paltinisu: pajdeja jako model w kulturze humanistycznej, Sejny 2001, która jest zapisem doświadczeń związanych z unikalną wspólnotą intelektualną skupioną wokół wybitnego filozofa rumuńskiego Constantego Noici.
} 


\section{Bibliografia}

Bierstedt R. (1976), Florian Znaniecki, „Przegląd Socjologiczny”, 28, s. 93-98.

Dulczewski Z. (1984), Florian Znaniecki. Życie i dzieło. Poznań: Wydawnictwo Poznańskie.

Gennep A. van, (2006), Obrzędy przejścia. Warszawa: PIW.

Hałas E. (1991), Znaczenia i wartości spoteczne: o socjologii Floriana Znanieckiego, Lublin: Redakcja Wydawnictw KUL.

Hałas E. (2007), Konwersja. Perspektywa socjologiczna. Warszawa: Wydawnictwo Naukowe Scholar.

Kurczewska J. (2005), Granica niejedno ma imię. Trzy podejścia teoretyczne [w:]: J. Kurczewska, H. Bojar (red.), Granice na pograniczach: z badań spoleczności lokalnych wschodniego pogranicza Polski. Warszawa: Wydawnictwo IFiS PAN, s. 365-396.

Kwaśniewski J. (1976), Pozytywna dewiacja społeczna, „Studia Socjologiczne” 3, s. 215-233.

Liiceanu G. (2018), O granicy. Kraków: Universitas.

Merton R.K. (1976) Sociological Ambivalence and Other Essays. New York: Free Press.

Pyszczek G. (2013), Nadnormalność jako zjawisko społeczne. Wokót koncepcji Floriana Znanieckiego.Warszawa: Wydawnictwo Akademii Pedagogiki Specjalnej.

Pyszczek G. (2016), Floriana Znanieckiego wizja reorganizacji kulturowej. „Humaniora. Czasopismo Internetowe”1, s. $51-67$.

Schmalenbach H. (1977), On Society and Experience. Chicago: University of Chicago Press.

Skudrzyk P. (2001), Amerykańska wspólnotowa filozofa polityczna. Katowice: Wydawnictwo Uniwersytetu Ślaskiego.

Szawiel T. (1982), Struktura społeczna a postawy i grupy etosowe. O możliwościach ewolucji społecznej. „Studia Socjologiczne" 1-2, s. 279-297.

Tomas W.I., Znaniecki F. (1976), Chtop polski w Europie i Ameryce, t. 1. Warszawa: PWN.

Tönnies F. (1988) Wspólnota i stowarzyszenie. Warszawa: PWN.

Turner F.J. (2014), O znaczeniu pogranicza w amerykańskiej historii, „Pogranicze. Polish Borderland Studies” 2/2, s. $139-162$.

Turner V. (2005), Gry społeczne, pola i metafory. Kraków: Wydawnictwo Uniwersytetu Jagiellońskiego.

Turner V., Turner E. (2009), Obraz i pielgrzymka w kulturze chrześcijańskiej. Kraków: Wydawnictwo Uniwersytetu Jagiellońskiego.

Turner V. (2010), Proces rytualny. Warszawa: PIW.

Turos L. (1995), Poglady Floriana Znanieckiego (1882-1958) na samowychowanie. „Edukacja Dorosłych” 4, s. 9-12.

Znaniecki F. (1967), Social Action. New York: Russell and Russell.

Znaniecki F. (1971), Nauki o kulturze. Warszawa: PWN.

Znaniecki F. (1978), Intelektualna Ameryka - napisat Europejczyk. „Kultura i Społeczeństwo” 4, s. 33-46.

Znaniecki F. (1990), Studium nad antagonizmem do obcych [w:] tenże, Wspótczesne narody. Warszawa: PWN, s. 265-358.

Znaniecki F. (2001), Socjologia wychowania, t. 2. Warszawa: Wydawnictwo Naukowe PWN.

Znaniecki F. (2008), Metoda socjologii. Warszawa: Wydawnictwo Naukowe PWN. 